\title{
MODEL PENGELOLAAN BADAN USAHA MILIK dAERAH (BUMD) DALAM RANGKA MEWUJUDKAN GOOD CORPORATE GOVERNANCE
}

\author{
Yudho Taruno Muryanto, djuwityastuti \\ Fakultas Hukum Universitas Sebelas Maret Surakarta \\ e-mail : yudho_fhuns@yahoo.com; djuwityastuti@gmail.com
}

\begin{abstract}
The study aims to obtain a management model (BUMD) of Local government-owned corporate in accordance with good corporate governance, those able to contribute that means both in term of shareholder or in term of stakeholder side. This research is empirical by using Satatute Aproach, Analytical and conceptual Aproach. Data used is primary data and seconadary data with instrument observartion, interview, and questionnaire. Sample is taken by using purposive sampling technique with dependent and independent variables. Data of the research is analyzed by using qualitative and quantitative analyses. Results of the research indicated that synchronization and harmonization of law products vertically and horizontally regulating management of BUMD. Vertical synchronization is conducted according to hierarchy of legislation order pattern and horizontal synchronization is conducted by analyzing about how far legislative rule regulating BUMD has a consistent functional relationship. Alternative models of BUMD management in attempts of realizing good corporate governance consist of two models, namely: The first is concept of BUMD Non-persero management by using "independent self-management'. Local government as authority can execute 'policy intervention'. The policy intervention is conducted in order to achieve goal of the BUMD Non-persero as a local government owned business with tasks of running social mission, public use, people well-being, and managing natural resource that very important for human life. The policy intervention is conducted by reenacting rule of local government such as rules of goverNomorr/Mayor/Regent that are regulating substantively strategic plan of the BUMD. The second is management of BUMD persero by using holding company with type of 'Programmed Procedure with combined business groups". The programmed procedure is selected because local government has diverse types of business.
\end{abstract}

Key words: Model of BUMD management, good corporate governance.

\begin{abstract}
Abstrak
Penelitian ini bertujuan untuk memperoleh sebuah model pengelolaan Badan Usaha Milik Daerah sesuai dengan prinsip-prinsip tata kelola perusahaan yang baik (good corporate governance). sehingga mampu memberikan konstribusi yang berati baik dari sisi shareholder maupun dari sisi stakeholder. Penelitian ini merupakan penelitian empiris dengan menggunakan pendekatan perundang-undangan, (Satatute Aproach), pendekatan konseptual (Analytical and conceptual Aproach). Data yang digunakan berupa data primer dan data sekunder yang diperoleh dengan menggunakan insntrumen observasi, wawancara dan kuisioner. Penarikan sampel dilakukan dengan cara purposive sampling dengan variable bebas dan terikat. Analisis data dilakukan dengan analisa kualitatif dan kuiantitatif. Hasil penelitian menunjukan perlunya dilakukan sinkronisasi dan harmonisasi produk hukum secara vertikal dari produk hukum dan horizontal yang mengatur tentang pengelolaan BUMD. Sinkronisasi secara vertikal dilakukan menurut hirarki tata urutan perundang-undangan dan sinkronisasi secara horizontal dilakukan dengan cara melakukan analisis seberapa jauh peraturan perundang-undangan yang mengatur tentang BUMD mempunyai hubungan fungsional secara konsisten. Alternatif model pengelolaan BUMD dalam rangka mewujudkan Good Corporate Governance dapat dilakukan dengan dua model yaitu : Konsep pengelolaan BUMD Non Persero dengan menggunakan swakelola mandiri. Kewenangan Pemerintah Daerah selaku pemegang otoritas dapat melakukan intervensi kebijakan, dengan menerbitkan peraturan kepala daerah baik peraturan Gubenur/Walikota/bupati yang secara subtansi mengatur tentang rencana strategis BUMD tersebut. Konsep pengelolaan BUMD persero dengan menggunakan model holding company dengan tipe prosedur terprogram dengan group usaha kombinasi. Dipilihnya model holding company dengan tipe prosedur terprogram karena tipe atau karakter jenis usaha yang ada di pemerintah daerah beragam.
\end{abstract}

Kata kunci : Model Pengelolaan BUMD, Good Corporate Governance 


\section{A. Pendahuluan}

Badan Usaha Milik Daerah (BUMD) merupakan usaha yang dimiliki oleh Pemerintah Daerah, yang tujuannya adalah sebagai salah satu sumber penerimaan daerah (PAD). Tapi pada kenyataannya bahwa BUMD yang ada selama ini belum mampu memberikan kontribusi yang signifikan terhadap pendapatan asli daerah (PAD), justru lebih banyak suntikan dana dari pemerintah daerah daripada keuntungan yang di dapat. Kondisi tersebut menjadi beban bagi APBD. Sehingga apa yang menjadi tujuan berdirinya BUMD adalah sebagai salah satu sumber pendapatan pemerintah daerah tidak tercapai.( P2 LIPI 2010).

Selain untuk kemakmuran dan kesejahteraan masyarakat keberadaan perusahaan daerah atau BUMD menurut Rodi Dohar Harahap adalah untuk mencari profit dalam bidang usahanya dalam rangka meningkatkan pendapatan asli daerah dari deviden yang disetorkan ke kas daerah. Deviden yang diperoleh dari BUMD tersebut kemudian akan menjadi pendapatan pemerintah daerah yang akan meningkatkan kemampuan APBD dalam membiayai pembangunan daerah. Pembagian konsep BUMD yang berorentasi pada bisnis dan pelayanan pada masyarakat sebenarnya memilki beberapa konsekuensi. Untuk BUMD yang berorentasi pada aspek bisnis diharapkan dapat memberikan keuntungan secara finansial. Sedangkan BUMD yang berorentasi pada pelayanan masyarakat diharapkan mampu memenuhi kebutuhan dan kepentingan masyarakat umum.( Rodi Dohar Harahap, 2011; )

Berdasarkan data dari Kemedagri aset BUMD 340,118 T sampai dengan Tahun2011 dan 310,716 T (90.06 \%) berasal dari BPD, Bank Perkreditan Rakyat (BPR) sekitar Rp.11,454 triliun (3,3 persen), perusahaan daerah air minum (PDAM) Rp 9,326 triliun (2,7 persen), serta aneka usaha sebesar Rp 11,622 triliun (3,4 persen). BUMD tercatat sebanyak 1.007 perusahaan yang bergerak di bidang usaha bank umum (BPD), bank perkreditan rakyat (BPR), air minum (PDAM), serta aneka usaha. Kontribusi laba BUMD tercatat sebesar Rp 10,372 triliun atau rata-rata rasio terhadap aset (ROA) sebesar 3,0 persen. Dengan kondisi di atas maka rasio laba yang dihasilkan dari BUMD dengan asset yang besar tidaklah seimbang. Kontribusi 3,0 \% dari total seluruh asat yang ada jauh dari harapkan terkait keberadaan BUMD. (http://www.depdagri.go.id/ news/2012/03/08/bumd-miliki-aset-Rp.343118triliun diakses oktober 2012)

Keberadaan Badan Usaha Milik Daerah selama ini tidak seperti Badan Usaha Milik Negara yang sebagian besar kegiatan usahanya sudah menerapkan prinsip-prinsip tata kelola perusahaan yang baik atau sesuai dengan prinsip-prinsip good corporate governance yang dituangkan dalam Keputusan Menteri BUMN Nomor Kep103/MBU/2002 tentang pembentukan komite audit bagi BUMN. Kondisi BUMN selangkah lebih maju dibandingkan dengan kegiatan usaha yang dilakukan oleh BUMD, dan bahkan perusahaan negara yang berbentuk perseroan sudah melangkah menjadi perusahaan publik dengan menerbitkan sahamnya di lantai bursa.

Salah satu permasalahan dalam pengelolaan dan pengembangan BUMD adalah, aspek hukum pengaturan terkait BUMD tidak secara khusus memberikan arahan dan pedoman dalam pengelolaan sebuah badan usaha yang dimiliki oleh daerah, seperti layaknya BUMN yang sudah mempunyai payung hukum UU Nomor 19 Tahun2003. Pengaturan terkait dengan BUMD terutama dalam hal pendirian yang masih menggunakan dasar Perda dan UU Nomor 5 Tahun 1962 tentang Perusahaan Daerah dirasa belum secara optimal menjawab tuntutan pengelolaan dan pengembangan BUMD. Selain permasalahan payung hukum tersebut, pengelompokan BUMD yang masih belum jelas menyebabkan distorsi terkait pengelolaan BUMD.

Menurut Kunarjo, (Seperti dikutip Rustian Komaludin, 2000) relatif masih kecilnya penerimaan bagian laba perusahaan daerah sebagai salah satu sumber pendapatan asli daerah (PAD), sebagian besar usahanya relatif berskala menengah dan kecil, di samping itu banyak pula diantaranya yang belum diselenggarakan berdasarkan asas ekonomi perusahaan, namun relatif lebih banyak didasarkan atas pertimbangan pelayanan publik. Menurut UU Nomor. 5 Tahun1962, terdapat rincian yang menetapkan bahwa penggunaan laba bersih perusahaan, setelah terlebih dulu dikurangi penyusutan. (Rustian Kamaludin, 2000 ).

Menurut ketentuan pasal 3 dalam Permendagri Nomor 3 Tahun 1998 tentang bentuk BUMD berupa perusahaan daerah dan berbentuk perseroan. Kedua bentuk BUMD tersebut diperlukan sebuah konsep atau model pengelolaan BUMD yang sesuai dengan karakeristik dan jenis BUMD itu sendiri. Dalam rangka pengelolaan BUMD secara profesional dan sesuai dengan prinsipprinsip good corporate governance dalam rangka memenuhi kepentingan shareholder (pemilik BUMD) dan stakeholder (masyarakat luas), maka diperlukan sebuah model dalam pengelolaanya. 


\section{B. Metode Penelitian}

Metode penelitian menggunakan Nomorrmatif empiris dibagi dalam dua tahap kajian. Tahap pertama, kajian mengenai hukum Nomorrmatif (perundang-undangan) yang berlaku khusunya yang berkaitan dengan BUMD dan tahap kedua kajian hukum empiris berupa penerapan (implementasi) pada peristiwa hukum in concreto yang guna mencapai tujuan yang telah ditentukan. (Abdulkadir Muhammad, 2004;53). Penarikan sample menggunakan purposive sampling. Data yang digunakan adalah data primer dan data sekunder dengan analisa data metode interprestasi teks (hermenetik) dan logika deduktif.

\section{Hasil Penelitian dan Pembahasan}

1. Penerapan Prinsip Good corporate governance (GCG),

Ada beberapa pengertian tentang good corporate governance (GCG), antara lain:

Menurut Organization for EcoNomormic cooperation and Development (OeCD) ada dua konteks definisi GCG, yaitu:

a. merupakan hubungan dan perilaku yang berbeda yang berkaitan dengan kewajiban para manajer, pemegang saham, karyawan, kreditur, pelanggan kunci, serta masyarakat, untuk membentuk strategi perusahaan.

b. tata kelola perusahaan berkaitan dengan seperangkat peraturan tentang kerangka hubungan dan perilaku perusahaan swasta, kemudian membentuk perumusan strategi perusahaan. Hal ini dapat disebut sebagai sisi Nomorrmatif dari tata kelola perusahaan (Nomorrmative side of corporate governance). (Siswanto Sutojo dan e. Jhon Aldrige, 2005)

Menurut The Indonesian institute for corporate governance (IIcg), GCG yaitu suatu proses dan struktur yang diterapkan dalam menjalankan perusahaan dengan tujuan utama meningkatkan nilai pemegang saham dalam jangka panjang, dengan tetap memperhatikan kepentingan stakeholders yang lain. (I Nyoman Tjager, 2003)

Berbagai keuntungan yang diperoleh dengan penerapan good corporate governance bagi suatu perusahaan, antara lain menurut Azhar Maksum, dijelaskan sebagai berikut:

a. Dengan good corporate governance proses pengambilan keputusan akan berlangsung secara lebih baik sehingga akan menghasilkan keputusan yang optimal, dapat meningkatkan efisiensi serta terciptanya budaya kerja yang lebih sehat.

b. good corporate governance akan memungkinkan dihindarinya atau sekurangkurangnya dapat diminimalkannya tindakan penyalahgunaan wewenang oleh pihak direksi dalam pengelolaan perusahaan.

c. Nilai perusahaan di mata investor akan meningkat sebagai akibat dari meningkatnya kepercayaan mereka kepada pengelolaan perusahaan tempat mereka berinvestasi.

d. Bagi para pemegang saham, dengan peningkatan kinerja perseroan, juga akan menaikkan nilai saham mereka dan juga nilai dividen yang akan mereka terima.

e. Karena dalam praktik good corporate governance karyawan ditempatkan sebagai salah satu stakeholder yang seharusnya dikelola dengan baik oleh perusahaan, maka motivasi dan kepuasan kerja karyawan juga diperkirakan akan meningkat.

f. Dengan baiknya pelaksanaan corporate governance, maka tingkat kepercayaan para stakeholders kepada perusahaan akan meningkat sehingga citra positif perusahaan akan naik.

g. Penerapan corporate governance yang konsisten juga akan meningkatkan kualitas laporan keuangan perusahaan. Manajemen akan cenderung untuk tidak melakukan rekayasa terhadap laporan keuangan, karena adanya kewajiban untuk mematuhi berbagai aturan dan prinsip akuntansi yang berlaku dan penyajian informasi secara transparan (Azhar Maksum, 2005).

Secara umum dalam rangka mewujudkan prinsip-prinsip good corporate governance dalam lingkup perusahaan terutama dalam pengelolaan BUMD tentunya harus dipahami dan di implementasikan ke lima prinsip tersebut secara nyata dan riil dalam praktik pengelolaan BUMD. Kelima prinsip tersenut antara lain : Transparancy (keterbukaan informasi), Accountability (akuntabilitas), Responsibility (pertanggungjawaban), Independency (kemandirian), dan Fairness (kesetaraan da kewajaran). (Thomas S Kaihatu. Jurnal Manajemen dan Kewirausahaan vol 2 Maret 2006). 


\section{Analisis Payung Hukum Pembentukan BUMd}

a. UU Nomor 5 Tahun1962 Tentang Perusahaan Daerah

Secara konseptual pembentukan sebuah BUMD di pemerintah daerah tidak terlepas dari ketentuan UU Nomor 5 Tahun1962 tentang perusahaan daerah yang merupakan cikal bakal munculnya BUMD. Dulu sebelum adanya UU Nomor 32 Tahun 2004 tentang pemerintahan daerah sebagaimana dirubah dengan ketentuan UU Nomor 12 Tahun2008 istilah yang digunakan adalah perusahaan daerah. Menurut ketentuan dalam undang-undang perusahaan daerah yang dimaksud dengan perusahaan daerah adalah:

"Semua perusahaan yang didirikan berdasarkan Undang-undang ini yang modalnya untuk seluruhnya atau untuk sebagian merupakan kekayaan Daerah yang dipisahkan, kecuali jika ditentukan lain dengan atau berdasarkan Undangundang"(UU Nomor5 Tahun 1962 pasal2).

Dalam ketentuan UU Nomor 5 Tahun 1962 tidak secara tegas mengatur tentang bentuk, konstruksi dan jenis dari sebuah BUMD, walaupun hal ini sudah dijawab dalam peraturan menteri dalam negeri Nomor 3 Tahun1998. Dalam UU Nomor 5 Tahun 1962 hanya menjelaskan syarat pendirian sebuah perusahaan daerah dengan perda. Dalam pembentukan sebuah peraturan daerah maka tidak bisa lepas dari unsur pemrintah Daerah dan DPRD selaku pemangku kebijakan dalam pemerintahan daerah. Dengan kondisi ini maka akan rentan terhadap unsur politik dan kepentingan para pihak yang terlibat dalam pembentukan sebuah perda dalam perusahaan daerah.Dalam bidang pengawasan akan berpotensi benturan kepentingan terkait dengan pengawasan kinerja sebuah perusahaan daerah (BUMD). Hal ini mengigat bahwa pengawasan yang ada di dalam perusahaan daerah menjadi kewenangan kepala daerah dengan segenap jajaranya, namun disisi lain juga dalam penentuan direksi atau pengelola perusahaan daerah (BUMD) tetap melibatkan unsur DPRD sebagai bahan pertimbangan pihak pemerintah daerah dalam memutuskan kebijakan terkait dengan BUMD. b. UU Nomor 32 TahunTahun 2004 sebagaimana dirubah dengan UU Nomor 12 Tahun 2008 Tentang Pemerintahan Daerah.

Dalam ketentuan undang-undang ini hanya mengatur tentang kewenangan daerah untuk membentuk sebuah BUMD dengan mendasarkan pada sebuah peraturan daerah. Undang-undang ini tidak secara detail mengatur tentang bagaimana prosedur dan mekanisme pembentukan sebuah perda. Dalam ketentuan tersebut dijelaskan:

"Pemerintah daerah dapat memiliki BUMD yang pembentukan, penggabungan, pelepasan kepemilikan dan/atau pembubaranya ditetapkan dengan perda yang berpedoman pada peraturan perundang-undangan" (UU Nomor 32 Tahun 2004 pasal 177).

Ketentuan tersebut sebenarnya secar subtansi hampir sama dengan ketentuan yang ada di dalam UU Nomor 5 Tahun 1962 hanya saja berbeda istilah yang dipakai. Dalam UU Nomor 5 Tahun 1962 dipakai istilah perusahan daerah dan dalam UU Nomor 32 Tahun 2004 sebagaimana dirubah dalam undangundang Nomor 12 Tahun2008 tentang pemrintahan daerah diistilahkan dengan BUMD.

C. Peraturan Menteri Dalam Negeri Nomor 3 Tahun 1990 Tentang Pengelolaan Barang Milik Daerah

Dalam ketentuan peraturan ini dmungkinkan pengaturan barang milik daerah terkait dengan perusahaan daerah ( BUMD), dikarenakan dalam pembentukan, pengelolaan serta menjalankan kegiatannya, perusahaan daerah (BUMD) juga menggunakan aset ataupun barang milik daerah sehingga berlaku ketentuan yang mengatur tentang pengunaan dan pemeliharaan barang milik daerah.

d. Peraturan Menteri Dalam Negeri Nomor 4 Tahun 1990 Tentang Kerjasama Antar Daerah

Dalam ketentuan permendagri ini diatur mengenai bentuk, mekanisme, prrosedur, dan tatacara kerjasama anatar daerah maupun pihak lain yang diatur dalam peraturan ini kaitannya dengan kerjasama perusahaan daerah (BUMD).

Selain itu daalm ketentuan ini mengatur juga bentuk kerjasama 
yang meliputi kerjasama manajemen, kontrak manajemen, pembelian saham, keagenan, penjualan saham, dll. Dalam ketentuan ini juga diatur mengenai persyaratan para pihak yang akan melakukan kerjasama dengan sebuah perusahaan daerah(BUMD), termasuk nilai investasinya.

e. Peraturan Menteri Dalam Negeri Nomor 3 Tahun 1998 tentang Bentuk BUMD

Dalam ketentuan peraturan ini secara sederhana dalam pasal 2 dan pasal 3 Permendagri Nomor 3 Tahun 1998 hanya mengatur tentang bentuk BUMD yang terdiri dari Perusahaan daerah Non persero dan perusahaan daerah perseroan (BUMD). BUMD yang berbentuk perusahaan daerah dibentuk berdasarkan perda sedangkan perusahaan daerah (BUMD) yang berbentuk perseroan dibentuk berdasarkan ketentuan UU Nomor 40 Tahun 2007.

f. Kepmendagri Nomor 50 Tahun 1999 Tentang Kepengurusan BUMD

Dalam pasal 2 disebutkan bahwa pengurus BUMD terdiri dari direksi dan badan pengawas. Terkait tugas, wewenang, dan tanggung jawab direksi diatur dalam pasal 3 sampai dengan pasal 8. Sedangkan terkait dengan tugas, fungsi, tanggung jawab dan wewenang badan pengawas diatur dalam pasal 18 samapai dengan pasal 22.

g. Kepmendagri Nomor 43 Tahun 2000 tentang pedoman kerjasama dengan pihak ketiga.

Dalam ketentuan ini perusahaan daerah dapat melakukan kerjasama dengan pihak ketiga sesuai dengan ketentuan pasal 1 ayat (3) dikatakan bahwa pihak ketiga adalah Pemerintah Propinsi, Pemerintah Kabupaten, Pemerintah Kota, perusahaan daerah (BUMD), Instansi/Lembaga Pemerintah dan Badan Usaha lain baik perorangan, nasional atau asing.

h. UU Nomor 40 Tahun 2007 tentang Perseroan

Secara subtansi dalam undangundang ini mengatur tentang "Iex specialist derogat legi generali”. Dalam undnag-undang perseroan secara khusus hanya mengatur tentang konstruksi bentuk, proses pendirian dan segala sesuatau yang berkaitan dengan status badan usaha yang berbentuk perseroan. Dalam ketentuan permendagri Nomor 3 Tahun 1998 dijelaskan bahwa bentuk dari BUMD dapat berbentuk perusahaan daerah maupun perseroan. Artinya konstruksi BUMD yang berbentuk perseroan terbatas (PT) harus tunduk pada ketentuan undang-undang ini.

\section{Sinkronisasi dan Harmonisasi Aspek Hukum dalam Pengelolaan Bumd}

a Teori Sinkronisasi Hukum

Dalam mengidentifikasi Nomorrma hukum, ada tiga konsepsi pokok yang harus diperhatikan seperti yang diungkapkan oleh Roni Hanitijo Soemitro.

"Pertama, konsepsi legistis positivistis, yang mengemukakan bahwa hukum itu identik dengan NomorrmaNomorrma tertulis yang dibuat dan diundangkan oleh lembaga atau oleh pejabat negara yang berwenang. Kedua, lebih menekankan pada arti pentingnya Nomorrma-Nomorrma hukum tidak tertulis untuk ikut serta dimasukkan sebagai hukum. Ketiga, hukum identik dengan keputusan hakim dan keputusan kepala adat. Sinkronisasi peraturan perundang-undangan dapat ditelaah baik secara vertikal maupun horisontal. Apabila sinkronisasi peraturan perundang-undangan itu ditelaah dari secara vertikal, berarti akan dilihat bagaimana hierarkhisnya".(Hanitijo, 1984;110).

Kemudian, jika sinkronisasi peraturan perundang-undangan hendak ditelaah secara horizontal, yang diteliti adalah sejauh mana peraturan perundang-undangan yang mengatur perbagai bidang itu mempunyai hubungan fungsional secara konsisten. Dengan melakukan sinkronisasi hukum maka akan diharapkan memperoleh jawaban menyeluruh terkait dengan permasalahan mengenai perundangundangan bidang tertentu, juga dapat mengungkapkan kelemahan-kelemahan yang ada pada perundang-undangan yang mengatur bidang-bidang tertentu. (Hanitijo, 1984;112). 
b Harmonisasi aspek hukum pengelolaan BUMD.

Dalam rangka sinkronisasi dan harmonisasi pengelolaan BUMD menurut teori sinkroniasi dan harmonisasi yang dikemukakan oleh Roni Hanitijo dapat dilakukan dengan dua cara yaitu dengan melakukan sinkronisasi peraturan perundang-undangan secara vertikal dan horisontal. Sinkronisasi terkait payung hukum pengelolaan BUMD secara vertikal dapat dilakukan dengan mengklasifikasikan peraturan yang mengatur tentang BUMD dari tata urutan yang paling tinggi tingkatanya sampai dengan yang paling rendah atau disusun secara hirarkinya.

Payung hukum pengelolaan BUMD bila dikaji menurut teori sinkronisasi secara vertikal sudah sesuai dengan hirarki dan tata urutan peraturan perundang undangan. Beberapa hal yang perlu diperhatikan adalah terkait dengan efektifitas dari peraturan perundangundangan tersebut. Hal ini dapat dilihat dari UU Nomor 5 Tahun1962 yang mana subtansi dari undang-undang tersebut belum mampu mengikuti perkembangan BUMD saat ini yang mana perlu dilakukan revisi maupun penggantian disesuaikan dengan kondisi dan perkembangan BUMD.

Harmonisasi dan sinkronisasi secara horisontal ditekankan pada sejauh mana peraturan perundang-undangan yang mengatur perbagai bidang itu mempunyai hubungan fungsional secara konsisten. Payung hukum yang mengatur tentang BUMD terdapat beberapa permasalahan ataupun perbedaan secara konsep dan subtansi sehingga tidak ada hubungan fungsional yang saling menunjang bahkan kontradiktif. Perbedaan tersebut dapat diinventarisir antara lain :

1) Terkait dengan pemahan dan konsep antara BUMD dan Perusahan daerah. Dalam UU Nomor 5 Tahun 1962 tentang perusahaan daerah, dan Permendagri Nomor 1 Tahun 1984 tentang tata cara pembinaan dan pengawasan perusda di lingkungan pemda tidak menyebut istilah BUMD namun menyebut dengan istilah "Perusahaan daerah". Sedangkan UU 32/2004, PP Nomor 3 Tahun 1998, PP Nomor
50 Tahun 1999 menyebut dengan istilah "BUMD". Perbedaan secara subtansi dan konsep yang mendasar dalam payung hukum BUMD dapat menimbulkan multi interprestasi. Dengan kondisi demikian muncul pertanyaan apakah BUMD identik dengan perusahaan daerah ataukah perusahaan daerah manjadi bagian dari BUMD. Menurut peneliti dilihat dari aspek subtansi dan fungiosnal dari payung hukum BUMD, dan dalam ketentuan PP Nomor 3 Tahun 1998 pasal 2 tentang bentuk BUMD dijelaskan bentuk BUMD ada dua yaitu Persuda dan PT. Ha ini sesuai dengan asas lek specialis derogat legi generali yang artinya peraturan yang khusus menjadi dasar atau yang diterapkan menggantikan peraturan yang bersifat umum.

2) Permasalahan bentuk dan jenis BUMD kaitannya terhadap pengelolaan BUMD. Dalam Permendagri Nomor 3 Tahun 1998 yang mengatur mengani bentuk BUMD dijelaskan:

(a) "Badan Usaha Milik Daerah yang bentuk hukumnya berupa Perusahaan Daerah, tunduk pada Peraturan Perundangundangan yang berlaku yang mengatur Perusahaan Daerah.

(b) Badan Usaha Milik Daerah yang bentuk hukumnya berupa Perseroan Terbatas tunduk pada Undang-undang Nomormor 1 Tahun 1995 (baca: UU Nomor 40 Tahun 2007) tentang Perseroan Terbatas dan peraturan pelaksanaannya". (Permendagri Nomor 3 Tahun 1998 pasal 3)

Bila kita kaji secara mendalam terkait dengan pembentukan sebuah BUMD diperlukan perda pendirian BUMD, baik itu yang berbentuk perusda maupun berbentuk perseroan. Hal ini dijelaskan pula dalam UU Nomor 5 Tahun 1992 pasal 177 UU Nomor 32 Tahun 2004 sebagaiman dirubah dengan UU Nomor 12 Tahun 2008 tentang Pemerintahan daerah. Dalam penjelasan pasal 3 tersebut akan menimbulkan permasalahan terutama dalam pengelolaan BUMD yang berbentuk 
perusda, mengingat konstruksi perusda secara teori badan hukum atau badan usaha menimbulkan multi tafsir. Kondisi ini dikarenakan status dan konsep perusda sendiri dari segi tata hukum perusahaan akan sulit diokonstruksikan, apakah perusda dapat dikatergorikan sebuah badan usaha yang berbentuk persekutuan perdata, firma, CV, atau yang lainya. Menurut hemat penulis perusda merupakan badan usaha yang berbadan hukum. Konstruksi perusda yang demikian akan berdampak pada hak dan kewajiban para pihak, tanggung jawab hukum para pengelolanya. Dengan ketentuan tersebut maka muncul pertanyaan mendasar jika BUMD yang didirikan dengan bentuk Perusda dan perseroan maka akan beda pengelolaan dan pengaturanya sehingga diperlukan sebuah "konsep/model" pengelolaan BUMD. Ketidaksinkronan akan menimbulkan disharmonisasi terkait aspek hukum yang mengatur BUMD, dengan demikian perlu dilakukan penguatan

governance struktur pada BUMD yang diharapkan dapat menciptakan keseimbangan pembagian peran dan kewenangan antar organ di BUMD agar dapat mewujudkan good corporate governance.

\section{Alternatif Model Pengelolaan BUMd}

a. Pengelolaan BUMD Non persero.

Berdasarkan jenis dan karakteristik BUMD, sesuai dengan Permendagri Nomor 3 Tahun 1998 yang membagi bentuk BUMD menjadi dua bentuk yaitu bentuk perusda dan bentuk perseroan. Bentuk BUMD yang dibagi dua tersebut tidak selamanya dapat diterapkan secara tegas dan pasti, hal ini terbukti di daerah provinsi DKI Jakarta yang membentuk BUMD dengan karakteristik yang berbeda yaitu berupa Badan Pengelola (seperti BP.Taman Hiburan Rakyat Lokasari). Dengan konstruksi dan bentuk BUMD seperti ini tentunya memerlukan pengelolaan dan penangan yang berbeda pula.

Permasalahan dalam rangka pengelolaan BUMD khususnya non persero sebagian besar terletak pada persoalan SDM dan manajerial dari pengelolaan BUMD. Untuk pengelolaan
BUMD non persero diperlukan beberapa konsep pengelolaan yang berbeda dengan BUMD persero. Dalam rangka pengelolaan BUMD non persero perlu diperhatikan beberapa latar belakang pembentukan yang mana dapat diinventarisir sebagai berikut.

a. BUMD dengan misi sosial, kemanfaatan umum, dan pelayanan jasa,

b. BUMD dengan bidang usaha yang menguasai hajat hidup orang banyak

c. BUMD dengan bidang usaha yang belum banyak diminati oleh sektor swasta.

Khusus untuk BUMD Non persero dimungkinkan dengan model pengelolaan BUMD dengan sistem swakelola mandiri. Konsep pengelolaan BUMD non persero ini menggunakan sistem pengawasan ataupun pembinaan secara bertanggungjawab dan intensif. Dalam mewujudkan kondisi tersebut diperlukan kebijakan yang sifatnya eksklusif. ekslusif disini diterjemahkan dalam pengelolaan BUMD Non persero dilakukan dengan pengawasan dan pembinaan secara langsung oleh pemangku kebijakan yang dilakukan oleh kepala daerah selaku pemegang otoritas tertinggi di Pemerintah Daerah. Kewenangan pemerintah daerah selaku pemegang otoritas dapat melakukan "intervensi kebijakan" dalam kontek yang positif terkait kinerja dari BUMD non persero melalui dewan pengawas. Intervensi kebijakan tersebut dilakukan untuk mencapai tujuan mengemban misi sosial, kemanfaatan umum, kesejahteraan masyarakat, yang menguasai hajat hidup orang banyak dengan menerbitkan peraturan kepala daerah baik peraturan Gubenur/Walikota/bupati yang secara subtansi mengatur tentang rencana strategis BUMD tersebut.

Alasan yang mengemuka pengelolaan BUMD non persero dengan model ini adalah salah satunya pemerintah dapat dengan mudah melakukan kontrol pengawasan dan dapat langsung melakukan eksekusi kebijakan. Dengan model demikian pemerintah daerah dapat memantau kinerja BUMD dengan lebih optimal tanpa mengesampingkan aspek pengelolaan BUMD secara profesional dan menurut tata kelola perusahaan yang baik. 
b. Pengelolaan BUMD persero

Sesuai rekomendasi dari hasil pertemuan Badan Kerjasama BUMD seluruh Indonesia yang ingin melakukan restrukturisasi BUMD dengan mengarahkan semua bentuk badan usaha menjadi konstruksi perseroan sesuai dengan ketentuan yang ada dalam UU Nomor 40 Tahun 2007 tentang perseroan terbatas. Salah satu tujuan utama pembentukan BUMD perseroan diimaksudkan untuk mewujudkan konsep tata kelola perusahaan yang baik. Dalam rangka mewujudkan kondisi tersebut maka idealnya konstruksi BUMD diarahkan berbentuk perseoran. Dalam rangka pengelolaan BUMD yang berbentuk perseroan dapat mengadopsi konsep pengelolaan perusahaan negara yang berada dibawah naungan Kementrian BUMN. Kerja sama di antara perusahaan-perusahaan yang dikenal dengan nama perusahaan kelompok consern atau group company atau perusahaan kelompok, secara umum dapat diberi pengertian sebagai suatu susunan dari perusahaanperusahaan yang secara yuridis tetap mandiri dan yang satu dengan yang lain merupakan satu kesatuan ekonomormi yang dipimpin oleh suatu perusahaan induk.(Pangaribuan, 1994;3). Konsep pengelolaaan perusahaan negara dikonsepkan menjadi sebuah konsep pengelolaan pada perusahaan kelompok dengan salah satu perusahaan menjadi perusahaan pengendali holding company dengan model prosedur terprogram.

Konsep prosedur terprogram menggunakan konsep perusahaan yang pertama kali didirikan dalam grupnya adalah perusahaan holding. Kemudian untuk setiap bisnis yang dilakukan akan dibentuk atau diakuisisi perusahaan lain, dimana perusahaan holding sebagai pemegang saham biasanya bersama-sama dengan pihak lain sebagai partner bisnis. Demikianlah, maka jumlah perusahaan baru sebagai anak perusahaan dapat terus berkembang jumlahnya seirama dengan perkembangan bisnis dari grup usaha yang bersangkutan. Hal tersebut dapat dilihat dalam diagram berikut ini: (Fuady, 2002;82).
Pembentukan perusahaan holding terpogram.

I.

A

II.

A1

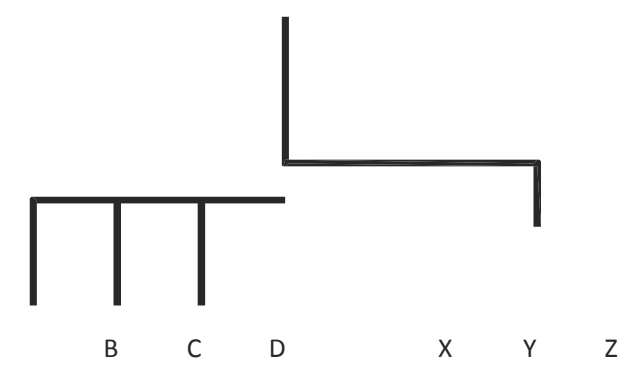

Keterangan gambar:

A : $\quad$ : Calon perusahaan holding

A1 : Perusahaan holding

B,C,D : Perusahaan baru dibentuk (anak perusahaan.

$\mathrm{X}, \mathrm{y}, \mathrm{Z} \quad$ : Perusahaan lain dengan kepemilikan yang berbeda/tidak saling berhubungan.

BC,D, : : memegang saham dari awal terbentuk perusahaan.

$\mathrm{X}, \mathrm{y}, \mathrm{Z} \quad$ : Pemegang saham secara akuisisi

\section{d. Simpulan :}

Dalam rangka mewujudkan konsep ideal pengelolaan BUMD sesuai dengan prinsip-prinsip good corporate governance ada beberapa hal yang harus dilakukan dalam rangka menyusun konsep tersebut antara lain.

1. Perlunya dilakukan sinkronisasi dan harmonisasi produk hukum yang mengatur tentang pengelolaan BUMD. Sinkronisasi dan harmonisasi dilakukan dengan cara vertikal dan horizontal terkait produk hukum yang mengatur tentang BUMD dari tingkatan yang paling tingi sampai tingkatan yang paling rendah. Sinkronisasi secara horizontal dilakukan dengan cara melakukan analisas seberapa jauh peraturan perundangundangan yang mengatur tentang BUMD mempunyai hubungan fungsional secara konsisten.

2. Alternatif model pengelolaan BUMD dalam rangka wewujudkan good corporate governance dapat dilakukan dengan dua model yaitu :

a. Konsep pengelolaan BUMD Non Persero dengan menggunakan swakelola mandiri. Kewenangan pemerintah daerah selaku pemegang otoritas dapat melakukan intervensi kebijakan dalam kontek 
yang positif terkait kinerja dari BUMD melalui dewan pengawas. Intervensi kebijakan tersebut dilakukan untuk mencapai tujuan dari BUMD selaku badan usaha daerah yang memiliki tujuan mengemban misi sosial, kemanfaatan umum, kesejahteraan masyarakat, dan yang menguasasi hajat hidup orang banyak, dengan menerbitkan peraturan Kepala Daerah baik peraturan Gubenur/ Walikota/Bupati yang secara subtansi mengatur tentang rencana strategis BUMD tersebut.

b. Konsep pengelolaan BUMD persero dapat dilakukan dengan konsep perusahaan grup dengan model holding company dengan beberapa tipe, salah satunya adalah prosedur terprogram dengan group usaha kombinasi, dipilihnya model holding company dengan tipe prosedur terprogram didasari berbagai pertimbangan antara lain :

1) Tipe atau karakter jenis usaha yang ada di pemerintah daerah.

Ada beberapa pertimbangan diterapkanya model prosedur terprogram dengan variasi usaha kombinasi, dikarenakan dengan model prosedur terprogram dimungkinkan munculnya jenis usaha baru yang ada di pemerintah daerah atau jenis usaha yang sudah ada di pemerintah daerah yang nantinya akan dijadikan perusahaan induk (perusahaan holding) sesuai dengan konsep prosedur terprogram yang bertujuan membentuk usaha baru yang akan dijadikan sebagai perusahaan induk.

2) Berdasarkan penggolongan usaha

Sesuai dengan tipe dan karakteristik pemerintah daerah yang majemuk dengan berbagai macam potensi dan jenis usahanya cocok untuk diterapkan usaha kombinasi. Hal ini tentunya untuk mengantisipasi berbagai potensi dan jenis usaha yang ada di pemerintah daerah yang ada untuk dijadikan satu dalam wadah usaha yang dinamakan holding company.

\section{E. Saran :}

1. Perlunya melakukan sinkronisasi dan harmonisasi terkait terhadap produk hukum yang mengatur dan terkait dengan BUMD.

2. Perlunya revisi terkait dengan UU Nomor 5 Tahun 1962 Tentang Perusahaan Daerah atau perlu dilakukan penggantian terhadap UU Perusahaan Daerah atau BUMD sesuai dengan kebutuhan dan dinamika perkembangan BUMD.

3. Perlunya dilakukan restrukturisasi terkait dengan konstruksi dan bentuk BUMD yang masih berbentuk perusahaan daerah terutama bidang usaha yang tidak menguasai hajat hidup orang banyak..

\section{F. Persantunan}

Puji syukur kami panjatkan kehadirat Allah SWT yang telah memberikan rahmat, karunia, taufik dan hidayah-Nya, sehingga dapat menyelesaikan laporan hasil penelitian yang berjudul "Model pengelolaan BUMD dalam rangka mewujudkan good corporate governance". Pada kesempatan ini kami menyampaikan ucapan terima kasih dan penghargaan yang setinggi-tingginya, pada :

1. Prof. Dr. Ir. Darsono, M.Si., selaku Ketua Lembaga Pneleitian dan Pengabdian Masyarakat Universitas Sebelas Maret Surakarta.

2. Prof. Dr. Hartiwiningsih S.H., M.Hum., selaku Dekan Fakultas Hukum Universitas Sebelas Maret Surakarta.

3. Biro Administrasi Perekonomian Pemerintah Provinsi Jawa Timur khususnya di bagian Penanaman Modal dan BUMD.

4. Badan Penanaman Modal dan Promosi Provinsi DKI Jakarta.

5. Bagian Perekonomian Pemerintah Kota Surabaya

Dan semua pihak yang telah membantu terlaksananya penelitian ini yang tidak bisa kami sebutkan satu persatu. 


\section{daftar Pustaka}

Anonim. 2010. P2 LIPI, 2010 Revitalisasi BUMD Dalam Perekonomian Daerah Lembaga IImu Pengetahuan Indonesia.

1962. UU Nomor 5 Tahun 1962 Tentang Perusahaan Daerah

2004. UU Nomor 32 Tahun 2004 sebagaimana dirubah dengan UU Nomor 12 Tahun 2008 tentang Pemerintahan Daerah.

2007. UU Nomor 40 Tahun 2007 Tentang Perseroan Terbatas

1998. Peraturan Pemerintah Nomor 3 Tahun1998 Tentang Bentuk BUMD

1999. Peraturan Pemerintah Nomor 50 Tahun 1999 Tentang Kepengurusan BUMD

1990. Permendagri Nomor 3 Tahun1990 Tentang Pengelolaan Barang Milik Daerah

1990. Permendagri Nomor 4 Tahun 1990 Tentang Kerjasama Anatar Perusahaan Daerah

Dengan Pihak Ketiga.

1990. Kepmendagri No 50 Tahun 1990 Tentang Kepegawaian BUMD

2000. Kepmendagri No 43 Tahun 2000 Tentang Kerjasama Dengan Pihak Ke Tiga

2002. Keputusan Menteri BUMN Nomor Kep-103/MBU/2002 Tentang Pembentukan Komite audit di BUMN

Abdulkadir Muhammad. 2004. hukum dan Penelitian hukum. Bandung: Citra Aditya.

Azhar Maksum. 2005. Pidato pengukuhan Azhar Maksum Sebagai Guru Besar Guru Besar Fakultas ekoNomormi Universitas Sumatera Utara dengan Judul "Tinjauan Atas Good Corporate Governance Di Indonesia"

e. Jhon Aldrige, Siswanto Sutojo. 2005. good corporate governance. Jakarta : Mulia Pustaka.

emy Pangaribuan. 1994, Perusahaan Kelompok, Seksi Hukum Dagang Fakultas Hukum Universitas Gadjah mada yogyakarta.

I Nyoman Tjager. 2003. corporate governance. Penerapan dan Kesempatan Bagi Komunitas Bisnis Indonesia. Jakarta : PT Prenhallindo

Munir Fuady. 2002. hukum Perusahaan, paradigma hukum bisnis. PT. Citra Aditya Bakti: Bandung.

Rodi Dohar Harahap. 2011. "BUMD diantara Ranah Hukum Publik dan Korporasi”, Makalah Asbanda.

Roni Hanitijo S, Rono Soemitro, 1984 Masalah-masalah sosiologi hukum. Bandung: Sinar Baru.

Rustian Kamaludin. 2000, "Peran dan pemberdayaan BUMD dalam rangka peningkatan perekoNomormian daerah" Makalah disajikan pada saat rapat koordinasi BUMD di Depdagri.

S Thomas Kaihatu. 2006. "good corporate governance dan Penerapannya di Indonesia". Jurnal Manajemen Dan Kewirausahaan. Volume 8 Nomormor 1, Maret 2006. Surabaya: Fakultas ekoNomormi Universitas Kristen Petra.

http://www.depdagri.go.id/news/2012/03/08/bumd-miliki-aset-Rp.343118-triliun diakses [oktober 2012] 